\title{
The role of the secondary cell wall in plant resistance to pathogens
}

\author{
Eva Miedes ${ }^{1,2}$, Ruben Vanholme ${ }^{3,4}$, Wout Boerjan ${ }^{3,4}$ and Antonio Molina ${ }^{1,2}$ * \\ ' Centro de Biotecnología y Genómica de Plantas, Universidad Politécnica Madrid, Madrid, Spain \\ 2 Departamento Biotecnología, Escuela Técnica Superior Ingenieros Agrónomos, Universidad Politécnica Madrid, Madrid, Spain \\ ${ }^{3}$ Department of Plant Systems Biology, VIB (Flanders Institute for Biotechnology), Gent, Belgium \\ ${ }^{4}$ Department of Plant Biotechnology and Bioinformatics, Ghent University, Gent, Belgium
}

\section{Edited by:}

Vincenzo Lionetti, Sapienza Università di Roma, Italy

Reviewed by:

William Underwood, University of California, Berkeley, USA

Lina Gallego-Giraldo, University of

North Texas, USA

\section{${ }^{*}$ Correspondence:}

Antonio Molina, Centro de

Biotecnología y Genómica de Plantas,

Universidad Politécnica Madrid,

Campus Montegancedo, M40

(Km. 38), Pozuelo de Alarcón,

Madrid 28223, Spain

e-mail: antonio.molina@upm.es
Plant resistance to pathogens relies on a complex network of constitutive and inducible defensive barriers. The plant cell wall is one of the barriers that pathogens need to overcome to successfully colonize plant tissues. The traditional view of the plant cell wall as a passive barrier has evolved to a concept that considers the wall as a dynamic structure that regulates both constitutive and inducible defense mechanisms, and as a source of signaling molecules that trigger immune responses. The secondary cell walls of plants also represent a carbon-neutral feedstock (lignocellulosic biomass) for the production of biofuels and biomaterials. Therefore, engineering plants with improved secondary cell wall characteristics is an interesting strategy to ease the processing of lignocellulosic biomass in the biorefinery. However, modification of the integrity of the cell wall by impairment of proteins required for its biosynthesis or remodeling may impact the plants resistance to pathogens. This review summarizes our understanding of the role of the plant cell wall in pathogen resistance with a focus on the contribution of lignin to this biological process.

Keywords: cell wall, plant pathogen, plant immunity, xylan, cellulose, lignin

\section{INTRODUCTION}

In their natural environments, plants are under continuous threat of biotic stresses caused by pathogenic bacteria, fungi, viruses, and oomycetes, that compromise plant survival and reproduction (Panstruga et al., 2009). Given that green plants are the ultimate source of energy for most other organisms, it is not surprising that plants have evolved a plethora of resistance mechanisms which are either constitutively present or induced after pathogen attack (Glazebrook, 2005; Panstruga et al., 2009). An important defense element common to all plants is the cell wall.

All the plant cells that are in developmental expansion have a constantly remodeled primary cell wall that mainly consists of carbohydrate-based polymers (classified as cellulose, hemicelluloses and pectins) and hydroxyproline-rich $O$-glycoproteins, such as extensins and arabinogalactan proteins (AGPs; Carpita and McCann, 2000). In addition, those cells that have completed their cellular expansion and need to reinforce their structure for functional reasons (e.g., to form vessel or fiber cells) generate a secondary cell wall that is mainly composed of cellulose, hemicelluloses (mostly xylans) and lignin (Cosgrove, 2005; Sarkar et al., 2009). Besides having multiple essential functions during plant development, plant cell walls also play important roles in preventing pathogen invasion. First, cell walls act as a passive barrier; local or extensive breakdown of the wall matrix is typically required for the progression of pathogen infection (Cantu et al., 2008; Hematy et al., 2009). Second, the cell wall is a reservoir of antimicrobial compounds, which are released during cell wall degradation (García-Olmedo et al., 2001; Schulze-Lefert, 2004; Vorwerk et al., 2004). Moreover, plants have a dedicated cell wall integrity (CWI) maintenance mechanism similar to that existing in fungi, which initiates responses to regulate CWI during plant development and in response to external stimuli (Wolf et al., 2012; Engelsdorf and Hamann, 2014). Impairment of CWI by pathogen attack or wounding results in the release of plant signaling molecules, the so-called Damage-Associated Molecular Patterns (DAMPs; Vorwerk et al., 2004; Cantu et al., 2008). DAMPs can modulate plant innate immune responses upon recognition by plant Pattern Recognition Receptors (PRRs), through molecular mechanisms that are similar to those regulating the activation of immune responses by Pathogen-Associated Molecular Patterns (PAMPs) derived from microbial pathogens (reviewed by Dodds and Rathjen, 2010; Macho and Zipfel, 2014; Malinovsky et al., 2014). The recognition of DAMPs and PAMPs by PRRs activates protein kinase cascades, which regulate downstream immune responses that can lead, among others, to cell-wall reinforcement (Ringli, 2010; Ferrari et al., 2013; Engelsdorf and Hamann, 2014; Malinovsky et al., 2014). Notably, in addition to its role in protecting plants against infection, the plant cell wall can also act as a source of nutrients from the pathogen point of view, thereby promoting pathogen growth and development (Cantu et al., 2008; Hematy et al., 2009).

Cell walls are also considered as a valuable feedstock for the production of second generation biofuels and bio-based chemicals. These so-called lignocellulosic feedstocks can either derive from agricultural and industrial practices, such as maize stover, straw and sugarcane bagasse, or from dedicated crops, such as fast growing grasses and trees, grown for the purpose of generating large volumes of lignocellulosic biomass. In both cases, engineering cell wall composition is a promising strategy to ease lignocellulosic biomass conversion toward fuels and chemicals 
in industrial processes (Simmons et al., 2010; Ong et al., 2014). Importantly, the changes in cell-wall composition needed for industrial biomass processing should not conflict with the principal biological roles of the cell wall as a supportive and protective structure. Indeed, some cell wall modifications result in negative repercussions on biomass yield (Bonawitz and Chapple, 2013). A better understanding of the processes underlying the yield-penalty in plants with modified cell walls has led to successful engineering strategies to recover the biomass yield, while maintaining the anticipated cell wall modifications (Petersen et al., 2012; Yang et al., 2013; Bonawitz et al., 2014). Likewise, cell wall modifications should not have negative repercussions on crop susceptibility toward pathogens. Clearly, a better understanding of the processes underlying the interactions between pathogens and the cell wall will support the development of plants with optimized lignocellulosic characteristics, without negatively affecting disease resistance.

A relatively large number of studies have described the influence of plant cell-wall modifications on pathogen infection (Cantu etal., 2008; Bellincampi etal., 2014; Malinovsky etal., 2014). Contra-intuitively, "weakening" the cell wall by knocking out essential genes involved in cell-wall biosynthesis sometimes leads to enhanced resistance toward specific pathogens. In this review, we summarize the consequences of secondary cell-wall modifications on pathogenic infection and link them with our current knowledge on the role of the cell wall in plant resistance to pathogens. Because lignin is both stress-induced and developmentally deposited in the secondary thickened cell wall and because it is a major target for lignocellulosic biomass engineering, we have put special emphasis on the effect of altering lignin amount and composition on pathogen infection and spread.

\section{THE EFFECT OF ALTERING CELL WALL POLYSACCHARIDES ON RESISTANCE TO PATHOGENS}

The contribution of the secondary cell wall to plant immunity has been mainly demonstrated through the characterization of plant mutants impaired in secondary wall composition (Cantu et al., 2008; Underwood, 2012). For instance, the resistance of a set of Arabidopsis thaliana (Arabidopsis herein) mutants defective in cellulose synthase (CESA) subunits required for secondary cell wall formation (i.e., CESA4, CESA7, and CESA8) toward a series of pathogens has been tested. These mutants make less cellulose, which results in collapsed xylem vessels, and therefore they are called irregular xylem mutants (irx5, irx3, and irx1, respectively). These mutants showed enhanced resistance to different pathogens, including the necrotrophic fungi Plectosphaerella cucumerina and Botrytis cinerea, the vascular bacterium Ralstonia solanacearum, and the biotrophic bacterium Pseudomonas syringae (Table 1; Hernández-Blanco et al., 2007). In line with these results, an Arabidopsis mutant defective in the MYB46 transcription factor that directly regulates the expression of genes required for secondary cell wall formation, including lignin and cellulose biosynthesis (among which CESA4, CESA7, and CESA8), also showed enhanced resistance to necrotrophic fungi (Ramírez et al., 2011). The disease resistance phenotype of irx 1, irx3, irx5, and myb46 mutants was in part explained by the constitutive activation of plant immune responses rather than by alterations of the passive wall barrier. In these mutants, the abscisic acid signaling pathway was constitutively active and antimicrobial peptides and tryptophan-derived metabolites accumulated to a higher extent than in wild-type plants (Hernández-Blanco et al., 2007; Sánchez-Vallet et al., 2010). Plant resistance to pathogens is also altered in Arabidopsis mutants affected in CESAs subunits required for cellulose biosynthesis of the primary cell wall, such as the CESA3 defective isoxaben resistant (ixr1)/constitutive expression of VSP (cev1) mutants (Ellis et al., 2002). The ixr1/cev1 mutant alleles are more resistant than wild-type plants to B. cinerea, P. syringae, and Erysiphe cichoracearum (Ellis et al., 2002), whereas their resistance to $R$. solanacearum and $P$. cucumerina does not differ from that of wild-type plants, which contrasts with the resistance phenotype of the secondary cell wall cellulose mutants, irx 1 , irx3 and irx5 (Hernández-Blanco etal., 2007). In ixr1/cev1 plants, the ethylene and jasmonic acid, but not the abscisic acid signaling pathway, are constitutively activated. These results with Arabidopsis ces $A$ mutants illustrate that specific immune responses can be activated by alteration of the CWI of either the primary or the secondary wall (Ellis etal., 2002; Hernández-Blanco et al., 2007).

A severe reduction in secondary wall thickness of fibers, but not that of xylem vessels, as it occurs in the Arabidopsis WALLS ARE THIN 1 (wat1) mutant, also increased resistance to vascular plant pathogens, such as the bacteria $R$. solanacearum and Xanthomonas campestris pv. campestris, the fungi Verticillium dahliae and Verticillium alboatrum, and the necrotrophic fungus $P$. cucumerina (Denancé et al., 2013). WAT1 encodes a tonoplast localized indole acetic acid (auxin) transporter (Pesquet et al., 2005; Ranocha et al., 2010, 2013). Auxin content was found to be lower in roots, but not in leaves of the wat1 mutant than in those of wild-type plants. In contrast, salicylic acid content was higher in the roots of the wat 1 mutant than in those of wild-type plants. Introduction in wat1 plants of NahG, the bacterial gene coding for a salicylic aciddegrading hydroxylase, restored full susceptibility to the bacteria (Denancé et al., 2013). These data and those obtained by comparative transcriptomic analyses of wat 1 and wild-type plants suggest that wat1-mediated resistance is again not caused by altering the strength of the wall as a passive barrier, but that it is dependent on the activation of immune responses, mainly localized in the vascular system, which are partially dependent on the salicylic acid pathway. This defense response has been described as "vascular immunity" (Denancé et al., 2013).

Alteration of glucoronoxylans and xyloglucans or modifications in the content of wall xylose, which is the major sugar component of these polysaccharides, also impacts resistance to pathogens in Arabidopsis. For example, plants with enhanced levels of wall-bound xylose, as it occurs in the de-etiolated3 (det3) and irx6 mutants (Brown etal., 2005; Rogers etal., 2005) or with alterations in the structure of xyloglucan, as in the $x y l 1$ 2 mutant (Sampedro et al., 2010), show an enhanced resistance to the necrotrophic fungus $P$. cucumerina (Delgado-Cerezo et al., 2012; Table 1). In contrast, impairment of the ERECTA (ER) gene encoding a PRR resulted in a reduced content of xylose besides other cell wall alterations in Arabidopsis (Sánchez-Rodríguez et al., 
Table 1 | Resistance phenotype of plants with alterations in secondary cell wall structure/composition.

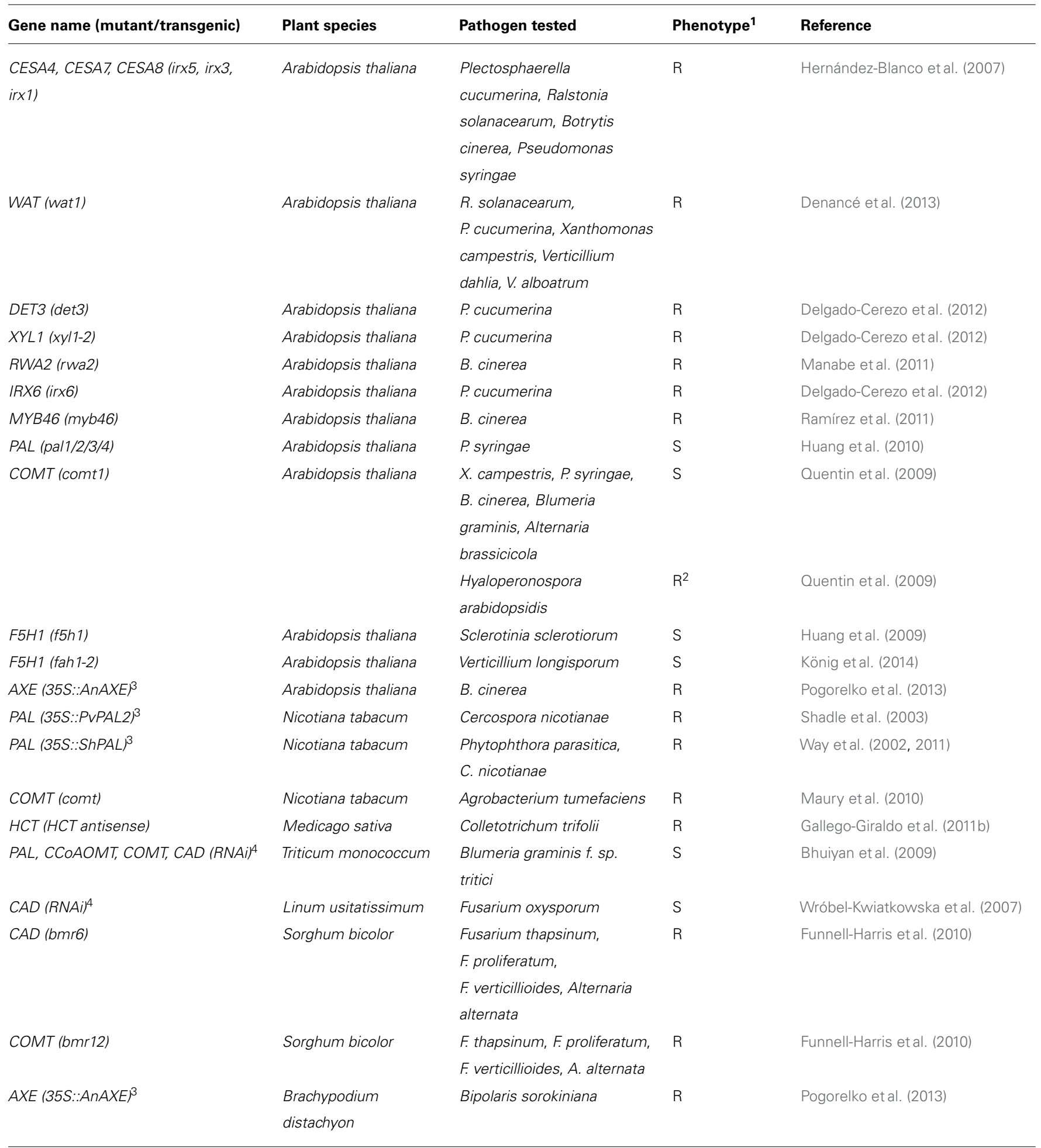

${ }^{1} R$; enhanced resistance compared with wild-type plants; $S$, enhanced susceptibility compared with wild-type plants.

2 Enhanced resistance to downy mildew was not correlated with increased plant defense responses in comt1 mutant, but coincided with a higher frequency of oomycete sexual reproduction within mutant tissues.

${ }^{3}$ Genes from Aspergillus nidulans (An), Phaseolus vulgaris (Pv) and Stylosanthes humilis (Sh).

${ }^{4}$ RNA interference constructs were made by a combined ligation/recombination (LR) method using plasmid pIPKTA3ON as the final GATEWAY destination vector (Bhuiyan etal., 2009) and a self-complementary hairpin RNA (hpRNA) of CAD gene, under the control of $35 S$ CaMV promoter, was used to silence CAD expression Wróbel-Kwiatkowska etal., 2007). 
2009). The er mutant was found to be more susceptible than wild-type plants to several pathogens, such as the necrotrophic fungus $P$. cucumerina, the vascular bacterium $R$. solanacearum and the vascular oomycete Pythium irregulare (Table 1; Godiard et al., 2003; Llorente et al., 2005; Adie et al., 2007). The enhanced susceptibility to $P$. cucumerina and the cell wall features of the er mutant, including its reduced xylose content, were restored to wild-type levels by mutations in SUPPRESSOR OF ERECTA 1 and 2 (SER1 and SER2), further suggesting a link between cell wall xylose content and resistance to pathogens (Sánchez-Rodríguez et al., 2009). Although several defense genes are constitutively upregulated in the ser 1 and ser 2 mutants, the precise molecular basis of their resistance has not yet been fully elucidated and the SER genes have not been characterized yet (Sánchez-Rodríguez et al., 2009). Arabidopsis mutants in the $G \beta$ and $G \gamma 1 / \gamma 2$ subunits of the heterotrimeric $\mathrm{G}$ protein (i.e., agb1 single and agg1 agg2 double mutants, respectively) also have a reduced content of xylose in their cell walls and are hypersusceptible to the necrotrophic fungi P. cucumerina and Alternaria brassicicola, the biotrophic bacterium $P$. syringae and the vascular fungus Fusarium oxysporum (Table 1; Llorente et al., 2005; Trusov et al., 2010; Klopffleisch etal., 2011; Delgado-Cerezo et al., 2012; Liu et al., 2013; Lorek et al., 2013; Torres etal., 2013). Interestingly, the reduced resistance of $a g b 1$ single and $a g g 1$ agg2 double mutants was found to be independent of defense pathways required for resistance to these pathogens, such as those regulated by abscisic acid, salicylic acid, jasmonic acid and ethylene, and those that regulate the biosynthesis of tryptophan-derived metabolites (Delgado-Cerezo et al., 2012; Lorek et al., 2013; Torres et al., 2013). It has been suggested that the reduced resistance in the $a g b 1$ and $a g g 1$ agg2 mutants is rather the direct consequence of a weakened cell-wall and a defective production of reactive oxygen species (ROS) upon pathogen infection (Delgado-Cerezo et al., 2012; Jiang et al., 2012; Liu et al., 2013; Lorek et al., 2013). Together, these data suggest that shifts in the xylose content of the cell wall, e.g., by altering the glucoronoxylan and xyloglucan content, are responsible, at least in part, for the altered susceptibility of some Arabidopsis secondary cell wall mutants to pathogens.

Cell wall polysaccharides such as xylan, (gluco)mannan and xyloglucan can be acetylated. Four Reduced Wall Acetylation genes (RWA1-RWA4) are involved in the acetylation of xylan during secondary wall biosynthesis. The expression of these genes is regulated by SND1, a transcriptional master switch of secondary wall biosynthesis (Lee et al., 2011). Remarkably, the Arabidopsis rwa2 mutant, that has $\sim 20 \%$ lower levels of polysaccharide $\mathrm{O}$-acetylation but no obvious alteration in growth and development, is more resistant than wild-type plants to the necrotrophic fungus B. cinerea (Manabe etal., 2011). The relevance of the degree of xylan acetylation in plant resistance to pathogens is further supported by the enhanced resistance to the necrotrophic fungi B. cinera and Bipolaris sorkiniana of transgenic Arabidopsis and Brachypodium distachyon, respectively, that have a reduced xylan acetylation due to overexpression of a xylan acetylesterase from Aspergillus nidulans (AnAXE; Table 1; Pogorelko et al., 2013). These data indicate that the degree of acetylation of specific secondary cell wall polymers might be a determinant of susceptibility to particular pathogens. In addition to RWA proteins, members of the trichome birefringence (TBR) and TBR-like (TBL) protein families are also involved in the $O$-acetylation of wall polysaccharides (Gille etal., 2011). The Arabidopsis powdery mildew resistant5 (pmr5) mutant, impaired in a TBL member, has a decrease in cell-wall esterification as demonstrated by Fourier transform infrared (FTIR) analysis, but it has yet to be demonstrated whether pmr5 cell walls have an altered polysaccharide O-acetylation (Vogel et al., 2004; Gille and Pauly, 2012). The pmr5 mutant is more resistant than wild-type plants to powdery mildew fungi (i.e., E. cichoracearum and E. orontii), whereas its resistance to the bacterium $P$. syringae or the oomycete Peronospora parasitica (re-named Hyaloperonospora arabidopsidis) was similar to that of wild-type plants (Vogel et al., 2004). Taken together, these data indicate that a decrease in cell wall acetylation in Arabidopsis resulted in an enhanced resistance to several fungi, but the molecular mechanisms explaining this resistance phenotype have yet to be elucidated.

Primary cell wall remodeling can also impact pathogen resistance, as exemplified by the enhanced resistance to some pathogens of mutants defective in the CESA subunits required for primary cell wall cellulose biosynthesis (i.e., ixr1/cev1; Ellis et al., 2002; Hernández-Blanco etal., 2007). Similarly, modification of the biosynthesis and/or structure (e.g., degree of methylesterification or acetylation) of wall pectins can affect pathogen resistance (Vogel et al., 2002, 2004; Lionetti et al., 2007; Raiola et al., 2011; Volpi etal., 2011; Bethke etal., 2014). The complex contribution of pectin amount/structure to the regulation of plant innate immunity has been nicely reviewed in several recent publications that also describe the different virulence mechanism used by pathogens to modify or degrade pectins in order to favor plant colonization (Ferrari et al., 2012; Lionetti et al., 2012; Bellincampi et al., 2014).

\section{PHENYLPROPANOID AND LIGNIN BIOSYNTHESIS}

Lignin is an aromatic polymer that is mainly deposited in secondary thickened cell walls where it provides strength and imperviousness. In monocot and dicot plants, lignin is mainly made from the monolignols coniferyl and sinapyl alcohol that give rise to the guaiacyl $(\mathrm{G})$ and syringyl (S) units in the lignin polymer, respectively. $p$-Coumaryl alcohol, that gives rise to the p-hydroxyphenyl $(\mathrm{H})$ units in the lignin polymer, is a minor monolignol that is slightly more abundant in monocot than in dicot cell walls. Lignin of gymnosperms is typically composed of $\mathrm{G}$ units and low levels of $\mathrm{H}$ units, but lacks $\mathrm{S}$ units. In several plant species, the traditional monomers are incorporated into the lignin in acylated forms. For instance, kenaf lignin is rich in sinapyl acetate-derived units, lignin of grasses has a high content of sinapyl $p$-coumarate-derived lignin units and poplar lignin incorporates sinapyl $p$-hydroxybenzoate (Morreel et al., 2004; Del Río et al., 2007; Lu and Ralph, 2008; Hatfield et al., 2009). In addition, plants do accept a range of other phenolics as lignin monomers. For example, lignin in wheat straw has relatively high levels of the flavonoid tricin (Del Río et al., 2012), whereas phenylpropanoid aldehydes and acids are found in the lignin of a range of wild-type and genetically engineered plants (Kim et al., 2000; Dauwe et al., 2007; Vanholme et al., 2012a; Van Acker et al., 2013, 2014). 


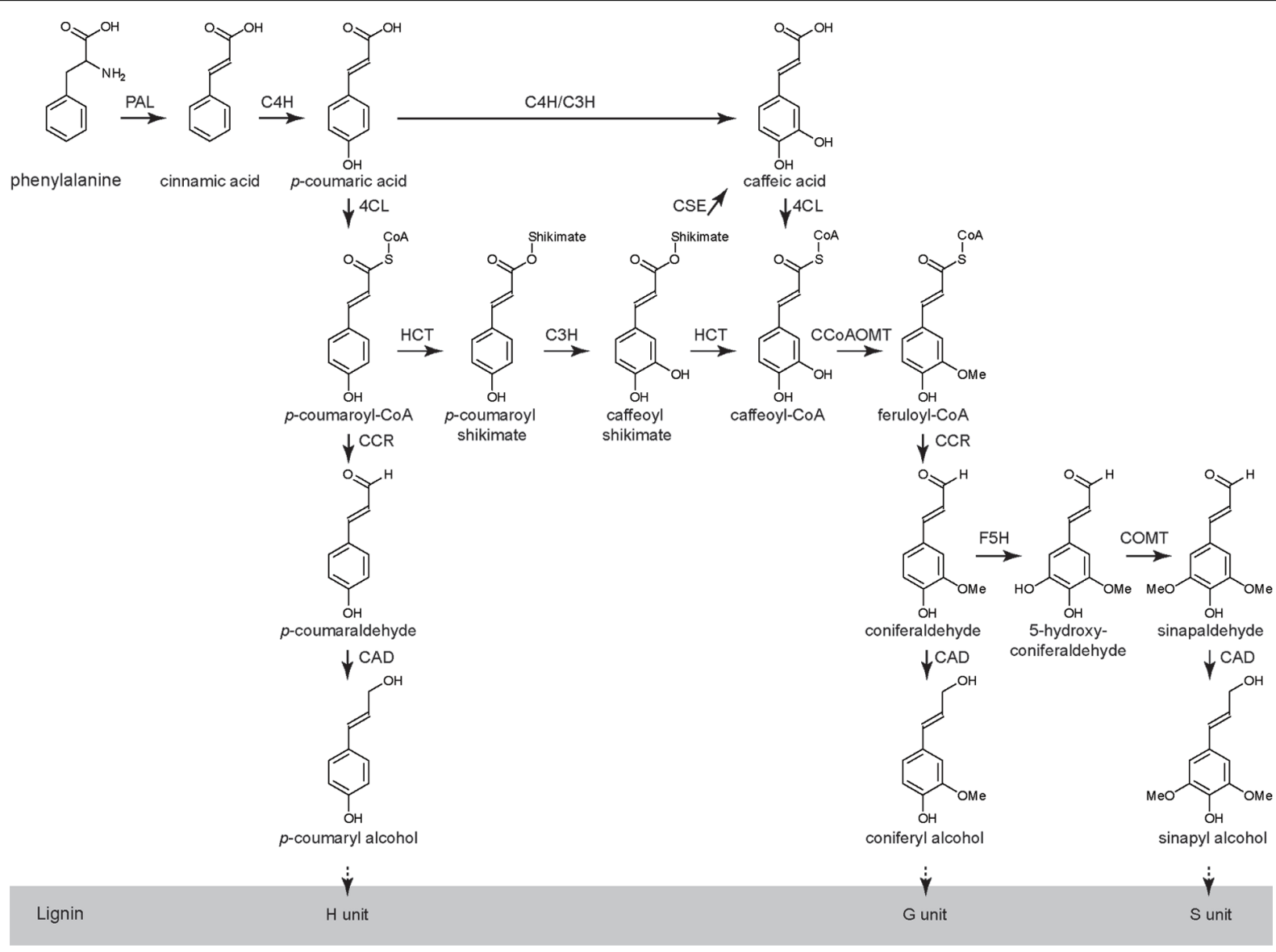

FIGURE 1 | The phenylpropanoid and monolignol biosynthetic pathway in Arabidopsis (adapted from Vanholme et al., 2010, 2013).

The lignin biosynthetic pathway is relatively well described in many species including Arabidopsis, tobacco, alfalfa and poplar, and is generally divided in two branches: (i) the general phenylpropanoid pathway from Phe to feruloyl-CoA and (ii) the monolignol-specific pathway from feruloyl-CoA to the monolignols (Figure 1). At least eleven enzymes are involved in the biosynthesis of the monolignols from Phe: phenylalanine ammonia-lyase (PAL), cinnamate 4-hydroxylase $(\mathrm{C} 4 \mathrm{H})$, 4-coumarate:CoA ligase (4CL), hydroxycinnamoyl-CoA shikimate/quinate hydroxycinnamoyl transferase (HCT), p-coumarate 3-hydroxylase $(\mathrm{C} 3 \mathrm{H})$, caffeoyl shikimate esterase (CSE), caffeoyl-CoA O-methyltransferase (CCoAOMT), cinnamoyl-CoA reductase (CCR), ferulate 5-hydroxylase (F5H), caffeic acid $O$ methyltransferase (COMT), and cinnamyl alcohol dehydrogenase (CAD; Figure 1; Boerjan et al., 2003; Bonawitz and Chapple, 2010; Vanholme et al., 2010, 2013). After their biosynthesis, the monolignols are transported to the cell wall where they are oxidized by laccases and/or peroxidases to monolignol radicals. Subsequently, these monolignol radicals couple in a combinatorial fashion with the formation of various types of chemical bonds of which the ether (8-O-4), resinol (8-8), and coumaran (8-5) bonds are the most prominent ones (Boerjan etal., 2003; Ralph et al., 2004; Vanholme et al., 2012a).
The biosynthesis and deposition of lignin in secondary cell walls is developmentally programmed and it is generally accepted that lignin provides a physical barrier against initial pathogen colonization (Buendgen et al., 1990; Bonello et al., 2003). In addition, lignin or lignin-like phenolic polymers are synthesized and rapidly deposited in cell walls in response to biotic and abiotic stresses and to cell wall structure perturbations (Caño-Delgado et al., 2003; Tronchet et al., 2010; Sattler and Funnell-Harris, 2013). The deposition of lignin in infected cells may prevent the spread of toxins and enzymes of the pathogen into the host and at the same time also the transfer of water and nutrients from the host cells to the pathogen (Smith et al., 2007). Both biotic and abiotic stresses have been shown to induce the expression of genes of the phenylpropanoid pathway in different tissues and cell cultures of several plants species, resulting in the enhanced accumulation of the corresponding enzymes, increased enzymatic activities and wall lignification (Kliebenstein et al., 2002; Bhuiyan et al., 2007; Zhao et al., 2009). For example, in Chinese cabbage (Brassica rapa L. ssp. pekinensis) infected with the necrotrophic bacterium Erwinia carotovora subsp. carotovora, transcriptomic analyses revealed that 12 genes putatively encoding enzymes involved in lignin biosynthesis were up-regulated (Zhang et al., 2007), and in Camelina sativa the expression of CsCCR2 was induced after 
inoculation with the necrotrophic fungus Sclerotinia sclerotiorum (Eynck et al., 2012). In cell suspension cultures of Linum usitatissimum treated with different fungal PAMPs, the expression of genes encoding PAL, CCR, and CAD was elevated, PAL activity was enhanced and monolignol-derived compounds accumulated (Hano et al., 2006). Similarly, in suspension cultured cells of a blast-resistant rice genotype (Oryza sativa L. cv. Gigante Vercelli) treated with cell wall hydrolysates from the fungal pathogen Magnaporthe oryzae, up-regulation of PAL genes was observed (Giberti et al., 2012). Also in wheat lignification acts as a defense response against pathogens: for example, S-rich lignin was found to accumulate during the hypersensitive reaction of wheat to Puccinia graminis infection (Menden et al., 2007), and S lignin was made in wheat sheath epidermal cells infected with $F$. proliferatum (Bishop et al., 2002). In contrast, no changes in the lignin content occurred in wheat leaves infected with Wheat Streak Mosaic Virus (Kofalvi and Nassuth, 1995).

In addition to its function in the biosynthesis of lignin, the phenylpropanoid pathway is required for the synthesis of numerous other phenolic compounds, such as stilbenes, coumarins, (neo-)lignans, phenylpropanoid conjugates, and flavonoids (Lo and Nicholson, 1998; Yu etal., 2000, 2005; Dixon et al., 2002; Naoumkina et al., 2010). Many of these compounds are considered to be phytoalexins, i.e., antimicrobial compounds implicated in plant defense (Daayf et al., 2012; König et al., 2014). Therefore, impairing steps of the phenylpropanoid pathway can result in either accumulation or reduced abundance of these compounds, often resulting in pleiotropic effects on plant resistance (Weiergang et al., 1996; Ruuhola and Julkunen-Tiitto, 2003; Dicko et al., 2005; Pan et al., 2006; Lozovaya et al., 2007). Phenolic compounds are also important in plant-pathogen recognition. For example, the expression of Agrobacterium tumefaciens Virulence (Vir) genes, needed for infection, is induced by phenolic compounds and infection of the host plant cannot take place in the absence of these compounds (Lee et al., 1992, 1995; Maury et al., 2010).

\section{EFFECT OF PHENOLIC CONTENT AND LIGNIN MODIFICATIONS ON PATHOGEN RESISTANCE}

Evidence for a role for lignin and soluble phenolics in plant defense has been obtained from the analysis of the pathogen resistance of transgenic plants and mutants with contrasting lignin amount or composition. For example, in tomato, the total content of soluble phenolics and lignin were significantly higher in varieties that were resistant to the vascular bacterium $R$. solanacearum than in susceptible ones, and this enhanced resistance was associated to a greater accumulation of lignin in roots upon bacterial infection, a process that was triggered by salicylic acid (Mandal et al., 2011, 2013). In tobacco, plants down-regulated for $P A L$ had reduced levels of chlorogenic acid and exhibited more rapid and extensive lesion development than wild-type plants upon infection with the fungal pathogen Cercospora nicotianae (Maher etal., 1994). The increased disease susceptibility in this $P A L$-suppressed line was suggested not to result from the inhibition of the pathogen-induced response, but rather from the decrease in the developmental accumulation of chlorogenic acid (Maher et al., 1994). However, the lignin content in this $P A L$ suppressed line was not determined and therefore it cannot be excluded that the enhanced susceptibility was caused by reduced lignin content or a weaker cell wall (Maher et al., 1994). In accordance with the latter studies, transgenic tobacco plants constitutively overexpressing $P A L$ genes showed a higher tolerance toward C. nicotianae and Phytophthora parasitica pv. nicotianae (Way etal., 2002, 2011; Shadle etal., 2003). Notably, COMT and CCOAOMT antisense tobacco lines were more resistant to Agrobacterium tumefaciens infection and showed a reduced tumor area and mass relative to wild-type plants (Maury et al., 2010). The phenolic compounds secreted by these antisense plants upon wounding did not induce the expression of the bacterial Vir genes equally well as those secreted from wounded wild-type plants (Maury et al., 2010). In other words, the Agrobacterium did not recognize its host because of the difference in soluble phenolics.

In cotton (Gossypium hirsutum), quantitative analysis of resistance to the wilt fungus $V$. dahliae revealed an association between increased lignification in the stems upon infection and resistance against wilt (Xu et al., 2011). In line with these data, overexpression of the cotton DIRIGENT1 gene, which enhances lignification, blocks the spread of V. dahliae (Shi et al., 2012). In alfalfa (Medicago sativa), down-regulation of the HCT gene leads to plants with reduced lignin levels, constitutive defense responses and enhanced tolerance to the fungal pathogen Colletotrichum trifolii. This activation of defense responses was hypothesized to be triggered by bioactive cell wall fragments released from the secondary cell wall (Gallego-Giraldo et al., 2011b). In melon (Cucumis melo), lignin accumulation upon infection was found to increase faster and to a higher level in lines resistant to the powdery mildew fungus Podosphaera fusca than in susceptible lines, and this differential accumulation correlated with enhanced PAL levels (Romero et al., 2008). Lignin composition seems to play an important role in pathogen resistance in flax, as RNAi-mediated suppression of a $C A D$ gene increased flax susceptibility to the vascular fungus F. oxysporum (Wróbel-Kwiatkowska et al., 2007).

Also in grasses the effect of modifying lignin biosynthesis on plant susceptibility has been investigated. For instance, in wheat (Triticum monococcum), silencing the monolignol biosynthesis genes TmPAL, TmCOMT, TmCCoAOMT, and TmCAD led to super-susceptibility of leaf tissues to the fungus $B$. graminis f. sp. tritici, the causal agent of powdery mildew disease (Bhuiyan et al., 2009). The increased accumulation of mono- and diferulates in the cell walls of oat and wheat upon infection with P. coronate sp. avenae and Agrobacterium sp., respectively, has been associated with resistance toward these pathogens (Ikegawa et al., 1996; Parrott et al., 2002). In transgenic rice overexpressing the NPR1 HOMOLOG 1 (NH1), a suppressor mutant screening was performed and a mutation in the SUPPRESSSOR OF NH1MEDIATED LESION FORMATION AND RESISTANCE (SNL6) gene, which encodes a CCR-like protein, was selected. snl6 mutants had a lower lignin content and a reduced resistance to the bacterium X. oryzae pv. oryzae (Bart et al., 2010). Mutations in BROWN MIDRIB 6 (BMR6) and BMR12 in sorghum (Sorghum bicolor L.) allowed the development of forage and grain lines with a reduced lignin content and modified lignin composition (Oliver et al., 2005). The bmr6 and bmr12 mutants, that are defective in $\mathrm{CAD}$ and COMT proteins, respectively, restricted the growth of 
different Fusarium spp. (F. thapsinum, F. proliferatum, and F. verticillioides), but not that of Gibberella fujikuroi (Bout and Vermerris, 2003; Sattler et al., 2009; Funnell-Harris et al., 2010). It is unknown whether the alteration of lignin composition or the accumulation of phenolic compounds is causative to the enhanced resistance of these sorghum mutants to Fusarium sp.

In trees, the contribution of lignin amount or composition on susceptibility to pathogens has been also investigated. For example, in eucalyptus, the deposition of lignin in necrophylatic periderm in the early stages of infection by Mycosphaerella explains the greater resistance of Eucalyptus nitens as compared with E. globulus (Smith et al., 2007). Comparative metabolite profiling of xylem tissue of Ulmus minor and Ulmus minor $\times$ Ulmus pumila after inoculation with Ophiostoma novo-ulmi showed that the hybrid has a faster defense response, which is characterized by an increase in the amount of lignin (Martin et al., 2007). Similarly, the infection of Pinus nigra by Sphaeropsis sapinea induces an increase in the deposition of lignin that was associated to resistance (Bonello and Blodgett, 2003). Interestingly, in hybrid poplar (Populus tremula $\times$ Populus alba) no increased disease incidence was observed in field-grown antisense COMT and CAD lines relative to that observed in wild-type trees, nicely showing that altered lignin biosynthesis does not necessarily negatively impact resistance to pathogens (Pilate et al., 2002; Halpin et al., 2007).

In summary, a general positive correlation between lignin amount and pathogen resistance has been observed, in particular when the plant-pathogen interaction concerns vascular pathogens, such as Fusarium sp., Xanthomonas sp. or Verticilium sp., that generally spread through the secondary-thickened xylem. In the majority of the examples analyzed, the impact of lignin modification on the regulation of other defense responses has not been studied, and it is not yet possible to conclude whether the role of lignin in resistance is merely passive or active by regulating specific immune responses.

\section{CONTRIBUTION OF LIGNIN TO PATHOGEN RESISTANCE IN Arabidopsis}

Several lines of evidence support a role for lignin in immunity of Arabidopsis to pathogens. The expression of some ligninbiosynthesis genes was induced, and the amount of lignin increased, by treating Arabidopsis with hormones (i.e., salicylic acid, abscisic acid or jasmonic acid) that regulate plant defense (Mohr and Cahill, 2007; Chen et al., 2009; GallegoGiraldo et al., 2011a). Similarly, infection of Arabidopsis with particular pathogens, such as the bacteria P. syringae pv. tomato and $X$. campestris, resulted in increased expression of ligninbiosynthesis genes and in higher lignin levels (Mohr and Cahill, 2007; Quentin etal., 2009). Experiments also hinted to specific stress-related roles for the different gene family members involved in certain enzymatic conversions. For example, the Arabidopsis CCR2 gene has been suggested to participate in the hypersensitive response to $X$. campestris as its expression was up-regulated after inoculation with this bacterium, in contrast to CCR1 which was preferentially expressed during development (Lauvergeat et al., 2001).

The analysis of Arabidopsis mutants defective in lignin biosynthesis and of transgenic plants overexpressing lignin biosynthesis genes has contributed to unravel the role of lignin in plant immunity. For example, two pal1/2/3/4 quadruple mutants with $20 \%$ and $25 \%$ residual lignin levels and 25\% residual salicylic acid levels, showed a stunted growth and were hypersusceptible to $P$. syringae. In addition, the total salicylic acid levels in the quadruple mutants after infection were about $50 \%$ of those in wild type, suggesting that pathogen-induced, salicylic acidmediated resistance might be partially impaired in this mutant (Huang et al., 2010). The Arabidopsis comt mutant was found to be slightly more susceptible than wild-type plants to $P$. syringae pv. tomato DC3000, but also to B. cinerea, A. brassicicola and $X$. campestris pv. campestris, and B. graminis $\mathrm{f}$. sp. hordei, that is a barley pathogen that does not colonize Arabidopsis plants (Quentin et al., 2009). Unexpectedly, asexual sporulation of the oomycete $H$. arabidopsidis, causing the downy mildew disease, was impaired in the comt mutant (Quentin et al., 2009). This phenotype was not correlated with an increased salicylic and jasmonic acid-dependent defense, but with a higher frequency of oomycete sexual reproduction within comt mutant tissues (Quentin et al., 2009). It was further proven that comt mutants accumulated soluble 5-hydroxyferuloyl-malate and that this compound promoted sexual oomycete reproduction in vitro (Quentin et al., 2009). Arabidopsis f5h1 mutants showed an increased susceptibility to the fungal pathogen S. sclerotiorum and to the vascular fungus Verticillium longisporum (Huang et al., 2009; König etal., 2014). The f5h1 mutants have similar amounts of lignin as compared to wild type, but lack $S$ units in the lignin and are sinapate ester deficient (Meyer et al., 1998; Vanholme et al., 2012b; König et al., 2014). Because sinapate esters inhibit fungal growth in vitro, their absence in f5h1 might explain the mutant's increased susceptibility toward fungal pathogens (König et al., 2014). Interestingly, the UGT72E2 over-expressing Arabidopsis line, in which lignin was not altered but the soluble phenylpropanoid coniferin accumulated, was less susceptible to V. longisporum (König etal., 2014). All together these results again strongly support that not only the lignin polymer but also the soluble phenolic pool plays a significant role in the defense of plants against pathogens. As described above for crops and other plant species, a general positive correlation between lignin amount and resistance toward pathogens has been observed in Arabidopsis too. However, a deeper characterization of the impact of the lignin alterations on Arabidopsis immune responses and its relation with the content and profile of phenolics is needed to elucidate the molecular mechanisms explaining the differential responses of the mutants to pathogen infection (Table 1).

In Arabidopsis, the plant's response to the perturbation of lignin has been studied in a collection of mutants, each mutated in a single gene of this pathway, by combining transcriptomics and metabolomics (Vanholme et al., 2012b; Figure 1). These analyses revealed that $c 4 h, 4 c l 1$, ccoaomtl, and ccrl mutants, that produced less lignin, upregulated the shikimate, methyl-donor, and phenylpropanoid pathways (i.e., the pathways supplying the monolignols), whereas, f5hl and comt mutants, that provoked lignin compositional shifts, downregulated the very same pathways (Vanholme et al., 2012b). Moreover, some of these mutant alleles revealed subtle differences in the metabolic and gene 


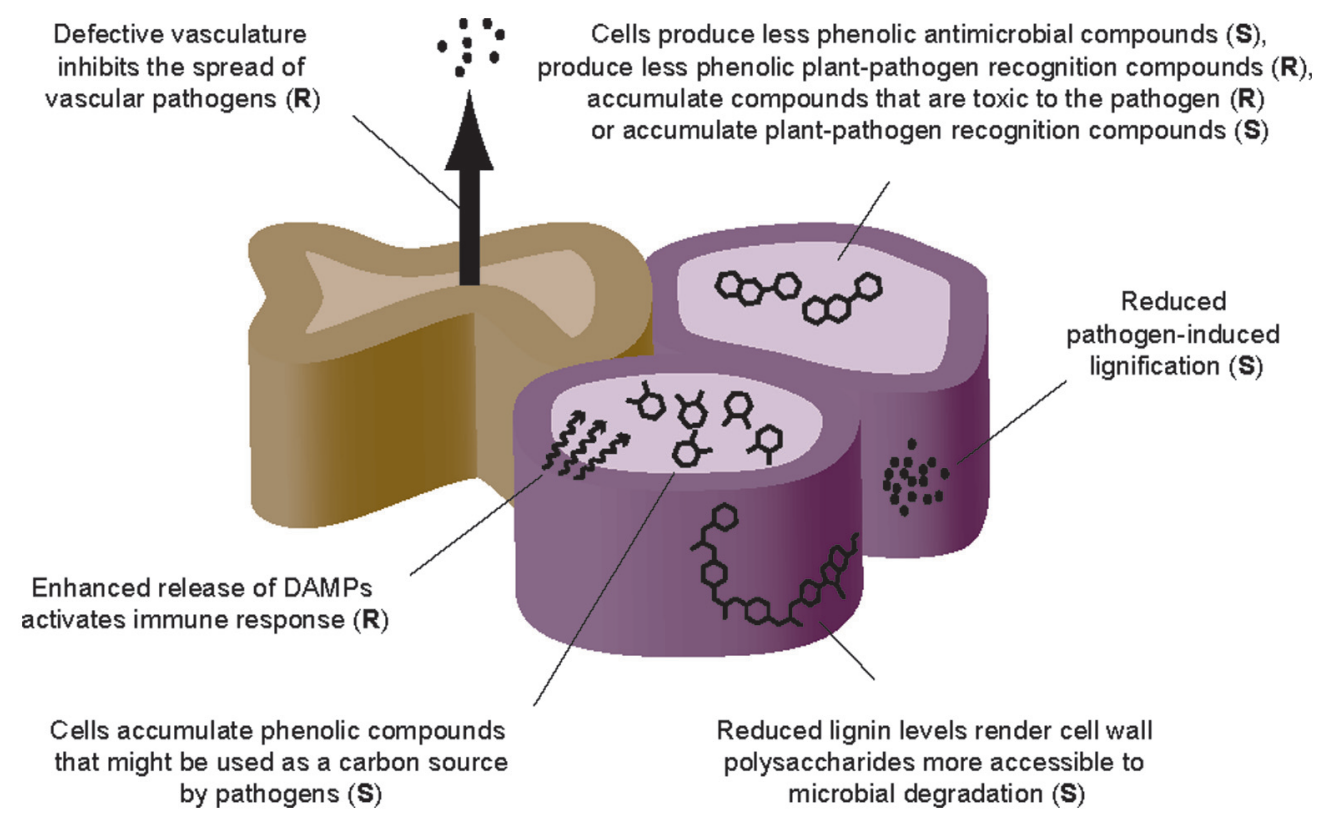

FIGURE 2 | Model illustrating lignin and secondary cell wall modifications resulting in enhanced resistance (R) or enhanced susceptibility (S) to pathogens.

expression profiles that might contribute to differential resistance responses to pathogens (Vanholme et al., 2012b). This collection of mutants represents a unique tool to further characterize the specific contribution of lignin biosynthesis to resistance against different types of pathogens in Arabidopsis.

\section{EFFECTS OF MODIFYING LIGNIN AND SECONDARY CELL WALL STRUCTURE ON PLANT PATHOGEN RESISTANCE: HYPOTHESES AND OPEN OUESTIONS}

Several hypotheses can be formulated to explain the resistance or the susceptibility observed in mutants and transgenic plants affected in the amount and/or composition of lignin and, more broadly, the secondary cell wall (Figure 2): (i) The perturbation of lignin or secondary cell wall structure modifies the physical barrier that pathogens must overcome to invade the plant. This perturbation can lead to enhanced resistance or susceptibility as these pathogens might lack the enzymes required for a proper degradation of this novel physical barrier, or wall degradation by pathogens is now facilitated, respectively; (ii) The reduced amount of lignin or the modification of lignin or secondary cell wall composition impacts the strength of the secondary cell wall resulting in collapsed xylem. A drop in vascular conduction might negatively contribute to plant colonization by vascular pathogens; (iii) The reduction of lignin amount and the modification of the secondary cell wall can loosen the wall, facilitating the constitutive or pathogen-induced release of cell wall DAMPs, which might trigger immune responses resulting in enhanced resistance to pathogens; (iv) The perturbation of the lignin pathway could lead to the accumulation of soluble phenolic compounds that are either toxic to some pathogens (e.g., resulting in a reduced virulence), or serve as a new carbon or nutrient source for pathogens that then will grow better (e.g., resulting in enhanced virulence); (v) Similarly, the perturbation of the lignin pathway could also lead to the accumulation or decrease of soluble phenolics that are plant-pathogen recognition compounds, which would result in an enhanced susceptibility or resistance, respectively. Although these hypotheses might explain some of the published phenotypes, other molecular explanations cannot be excluded and a deeper molecular and biochemical characterization is required for a better understanding of the contribution of the secondary cell wall to pathogen resistance.

\section{PERSPECTIVES}

Lignin negatively impacts the conversion of lignocellulosic biomass into fermentable sugars, making it one of the most important limiting factors in the processing of plant biomass to pulp and biofuels (Chen and Dixon, 2007; Dien et al., 2009; Van Acker et al., 2013). Hence, modifications of the plant secondary cell wall can contribute to the improvement of biomass processing in paper mills and bio-refineries. However, one critical question for lignocellulosic feedstock development is whether engineering the secondary cell wall, including its lignin content and composition, will affect plant defense against pathogens. In this review, we have summarized the role of the cell wall in plant resistance toward pathogens. We conclude that plants with altered secondary cell walls may either have an enhanced or a reduced resistance toward pathogens, or no effect at all, depending on the alterations made and the pathogens tested. Because our current knowledge on the role of the cell wall (primary or secondary) in defense against pathogens is still fragmentary, it is difficult to predict how specific alterations of the cell wall will influence a plant's resistance toward pathogens. A deeper investigation of the role of the plant cell wall 
in pathogen resistance and the biochemical networks underlying this resistance is required.

\section{ACKNOWLEDGMENTS}

We gratefully acknowledge funding through the Spanish Ministry of Economy and Competitiveness (MINECO, grants BIO201232910 and PIM2010PKB-00749), the European Commission's Directorate-General for Research within the 7th Framework Program (FP7/2007-2013) under the grant agreement No. 311804 (SUNLIBB) and No. 270089 (MULTIBIOPRO), Stanford University's Global Climate and Energy Project (GCEP, "Lignin management: optimizing yield and composition in lignin-modified plants"), and the Multidisciplinary Research Partnership "Biotechnology for a Sustainable Economy" (01MRB510W) of Ghent University. Ruben Vanholme is indebted to the Research Foundation-Flanders for a postdoctoral fellowship. Eva Miedes was a JdC postdoctoral fellow from the Spanish MINECO.

\section{REFERENCES}

Adie, B. A., Perez-Perez, J., Perez-Perez, M. M., Godoy, M., Sanchez-Serrano, J. J., Schmelz, E. A., et al. (2007). ABA is an essential signal for plant resistance to pathogens affecting JA biosynthesis and the activation of defenses in Arabidopsis. Plant Cell 19, 1665-1681. doi: 10.1105/tpc.106.048041

Bart, R. S., Chern, M., Vega-Sánchez, M. E., Canlas, P., and Ronald, P. C. (2010). Rice Snl6, a cinnamoyl-CoA reductase-Like gene family member, is required for NH1mediated immunity to Xanthomonas oryzae pv. oryzae. PLoS Genet. 6:e1001123. doi: 10.1371/journal.pgen.1001123

Bellincampi, D., Cervone, F., and Lionetti, V. (2014). Plant cell wall dynamics and wall-related susceptibility in plant-pathogen interactions. Front. Plant Sci. 5:228. doi: $10.3389 /$ fpls. 2014.00228

Bethke, G., Grundman, R. E., Sreekanta, S., Truman, W., Katagiri, F., and Glazebrook, J. (2014). Arabidopsis PECTIN METHYLESTERASEs contribute to immunity against Pseudomonas syringae. Plant Physiol. 164, 1093-1107. doi: $10.1104 /$ pp.113.227637

Bhuiyan, N., Liu, W., Liu, G., Selvaraj, G., Wei, Y., and King, J. (2007). Transcriptional regulation of genes involved in the pathways of biosynthesis and supply of methyl units in response to powdery mildew attack and abiotic stresses in wheat. Plant Mol. Biol. 64, 305-318. doi: 10.1007/s11103-007-9155-x

Bhuiyan, N. H., Selvaraj, G., Wei, Y., and King, J. (2009). Gene expression profiling and silencing reveal that monolignol biosynthesis plays a critical role in penetration defence in wheat against powdery mildew invasion. J. Exp. Bot. 60, 509-521. doi: 10.1093/jxb/ern290

Bishop, D. L., Chyatterton, N. J., Harrison, P. A., and Hatfield, R. D. (2002). Changes in carbohydrate partitioning and cell wall remodelling with stressinduced pathogenesis in wheat sheaths. Physiol. Mol. Plant Pathol. 61, 53-63. doi: 10.1016/S0885-5765(02)90416-9

Boerjan, W., Ralph, J., and Baucher, M. (2003). Lignin biosynthesis. Annu. Rev. Plant Biol. 54, 519-546. doi: 10.1146/annurev.arplant.54.031902. 134938

Bonawitz, N. D., and Chapple, C. (2010). The genetics of lignin biosynthesis: connecting genotype to phenotype. Annu. Rev. Genet. 44, 337-363. doi: 10.1146/annurev-genet-102209-163508

Bonawitz, N. D., and Chapple, C. (2013). Can genetic engineering of lignin deposition be accomplished without an unacceptable yield penalty? Curr. Opin. Plant Biol. 24, 336-343. doi: 10.1016/j.copbio.2012.11.004

Bonawitz, N. D., Kim, J. I., Tobimatsu, Y., Ciesielski, P. N., Anderson, N. A., Ximenes, E., et al. (2014). Disruption of mediator rescues the stunted growth of a lignin-deficient Arabidopsis mutant. Nature 15, 509, 376-380. doi: 10.1038/ nature 13084

Bonello, P., and Blodgett, J. T. (2003). Pinus nigra-Sphaeropsis sapinea as a model pathosystem to investigate local and systemic effects of fungal infection of pines. Physiol. Mol. Plant Physiol. 63, 249-261. doi: 10.1016/j.pmpp.2004. 02.002

Bonello, P., Storer, A. J., Gordon, T. R., Wood, D. L., and Heller, W. (2003). Systemic effects of Heterobasidion annosum on ferulic acid glucoside and lignin of presymptomatic ponderosa pine phloem, and potential effects on bark-beetle-associated fungi. J. Chem. Ecol. 29, 1167-1182. doi: 10.1023/ A: 1023833707382

Bout, S., and Vermerris, W. (2003). A candidate-gene approach to clone the sorghum Brown midrib gene encoding caffeic acid O-methyltransferase. Mol. Genet. Genomics 269, 205-214.

Brown, D. M., Zeef, L. A. H., Ellis, J., Goodacreb, R., and Turner, S. R. (2005). Identification of novel genes in Arabidopsis involved in secondary cell wall formation using expression profiling and reverse genetics. Plant Cell 17, 2281-2295. doi: $10.1105 /$ tpc. 105.031542

Buendgen, M. R., Coors, J. G., Grombacher, A. W., and Russell, W. A. (1990). European corn borer resistance and cell wall composition of three maize populations. Crop Sci. 30, 505-510. doi: 10.2135/cropsci1990.0011183X00 $3000030005 \mathrm{x}$

Caño-Delgado, A., Penfield, S., Smith, C., Catley, M., and Bevan, M. (2003). Reduced cellulose synthesis invokes lignification and defense responses in Arabidopsis thaliana. Plant J. 34, 351-362. doi: 10.1046/j.1365-313X.2003. 01729.x

Cantu, D., Vicente, A. R., Labavitch, J. M., Bennett, A. B., and Powell, A. L. (2008). Strangers in the matrix: plant cell walls and pathogen susceptibility. Trends Plant Sci. 13, 610-617. doi: 10.1016/j.tplants.2008.09.002

Carpita, N., and McCann, M. (2000). “The cell wall," in Biochemistry and Molecular Biology of Plants, eds B. B. Buchanan, G. Wilhelm, and R. L. Jones (Rockville, IL: American Society of Plant Physiologists), 52-108.

Chen, F., and Dixon, R. A. (2007). Lignin modification improves fermentable sugar yields for biofuel production. Nat. Biotechnol. 25, 759-761. doi: 10.1038/ nbt1316

Chen, Z., Zheng, Z., Huang, J., Lai, Z., and Fan, B. (2009). Biosynthesis of salicylic acid in plants. Plant Signal. Behav. 4, 493-496. doi: 10.4161/psb.4. 6.8392

Cosgrove, D. J. (2005). Growth of the plant cell wall. Nat. Rev. Mol. Cell Biol. 6, 850-861. doi: 10.1038/nrm1746

Daayf, F., El Hadrami, A., El-Bebany, A. F., Henriquez, M. A., Yao, Z., Derksen, H., et al. (2012). "Phenolic compounds in plant defense and pathogen counterdefense mechanisms," in Recent Advances in Polyphenol Research, eds V. Cheynier, P. Sarni-Manchado, and S. Quideau (Oxford, UK: Wiley-Blackwell). doi: 10.1002/9781118299753.ch8

Dauwe, R., Morreel, K., Goeminne, G., Gielen, B., Rohde, A., Van Beeumen, J., et al. (2007). Molecular phenotyping of lignin-modified tobacco reveals associated changes in cell-wall metabolism, primary metabolism, stress metabolism and photorespiration. Plant J. 52, 263-285. doi: 10.1111/j.1365-313X.2007. 03233.x

Del Río, J. C., Marques, G., Rencoret, J., Martínez, Á. T., and Gutiérrez, A. (2007). Occurrence of naturally acetylated lignin units. J. Agric. Food Chem. 55, 54615468. doi: 10.1021/jf0705264

Del Río, J. C., Rencoret, J., Prinsen, P., Martínez, Á. T., Ralph, J., and Gutiérrez, A. (2012). Structural characterization of wheat straw lignin as revealed by analytical pyrolysis, 2D-NMR, and reductive cleavage methods. J. Agric. Food Chem. 60, 5922-5935. doi: 10.1021/jf301002n

Delgado-Cerezo, M., Sánchez-Rodríguez, C., Escudero, V., Miedes, E., Fernández, P. V., Jordá, L., et al. (2012). Arabidopsis heterotrimeric G-protein regulates cell wall defense and resistance to necrotrophic fungi. Mol. Plant 5, 98-114. doi: $10.1093 / \mathrm{mp} / \mathrm{ssr} 082$

Denancé, N., Ranocha, P., Oria, N., Barlet, X., Rivière, M. P., Yadeta, K. A., et al. (2013). Arabidopsis wat1 (walls are thin1) mediated resistance to the bacterial vascular pathogen, Ralstonia solanacearum, is accompanied by crossregulation of salicylic acid and tryptophan metabolism. Plant J. 73, 225-239. doi: 10.1111/tpj.12027

Dicko, M. H., Gruppen, H., Barro, C., Traore, A. S., Van Berkel, W. J. H., and Voragen, A. G. J. (2005). Impact of phenolic compounds and related enzymes in sorghum varieties for resistance and susceptibility to biotic and abiotic stresses. J. Chem. Ecol. 31, 2671-2688. doi: 10.1007/s10886-0057619-5

Dien, B. S., Sarath, G., Pedersen, J. F., Sattler, S. E., Chen, H., Funnell-Harris, D. L., et al. (2009). Improved sugar conversion and ethanol yield for forage sorghum (Sorghum bicolor L. Moench) lines with reduced lignin contents. Bioenergy Res. 2, 153-164. doi: 10.1007/s12155-009-9041-2

Dixon, R. A., Achnine, L., Kota, P., Liu, C. J., Reddy, M. S., and Wang, L. (2002). The phenylpropanoid pathway and plant defence - a genomics 
perspective. Mol. Plant Pathol. 3, 371-390. doi: 10.1046/j.1364-3703.2002. 00131.x

Dodds, P. N., and Rathjen, J. P. (2010). Plant immunity: towards an integrated view of plant-pathogen interactions. Nat. Rev. Genet. 11, 539-548. doi: $10.1038 / \operatorname{nrg} 2812$

Ellis, C., Karafyllidis, I., Wasternack, C., and Turner, J. G. (2002). The Arabidopsis mutant cev1 links cell wall signaling to jasmonate and ethylene responses. Plant Cell 14, 1557-1566. doi: 10.1105/tpc.002022

Engelsdorf, T., and Hamann, T. (2014). An update on receptor-like kinase involvement in plant cell wall integrity maintenance. Ann. Bot. doi: 10.1093/aob/mcu043 [Epub ahead of print].

Eynck, C., Séguin-Swartz, G., Clarke, W. E., and Parkin, I. A. (2012). Monolignol biosynthesis is associated with resistance to Sclerotinia sclerotiorum in Camelina sativa. Mol. Plant Pathol. 13, 887-899. doi: 10.1111/j.1364-3703.2012. 00798.x

Ferrari, S., Savatin, D. V., Sicilia, F., Gramegna, G., Cervone F., and DeLorenzo, G. (2013). Oligogalacturonides: plant damage associated molecular patterns and regulators of growth and development. Front. Plant Sci. 4:49. doi: 10.3389/fpls.2013.00049

Ferrari, S., Sella, L., Janni, M., Favaron, F., and D'Ovidio, R. (2012). Transgenic expression of polygalacturonase-inhibiting proteins in Arabidopsis and wheat increases resistance to the flower pathogen Fusarium graminearum. Plant Biol. 14, 31-38. doi: 10.1111/j.1438-8677.2011.00449.x

Funnell-Harris, D. L., Pedersen, J. F., and Sattler, S. E. (2010). Alteration in lignin biosynthesis restricts growth of Fusarium spp. in brown midrib sorghum. Phytopathology 100, 671-681. doi: 10.1094/PHYTO-1007-0671

Gallego-Giraldo, L., Escamilla-Trevino, L., Jackson, L. A., and Dixon, R. A. (2011a). Salicylic acid mediates the reduced growth of lignin down-regulated plants. Proc. Natl. Acad. Sci. U.S.A. 108, 20814-20819. doi: 10.1073/pnas. 1117873108

Gallego-Giraldo, L., Jikumaru, Y., Kamiya, Y., Tang, Y., and Dixon, R. A. (2011b). Selective lignin down-regulation leads to constitutive defense response expression in alfalfa (Medicago sativa L.). New Phytol. 190, 627-639. doi: 10.1111/j.14698137.2010.03621.x

García-Olmedo, F., Rodríguez-Palenzuela, P., Molina, A., Alamillo, J. M., LópezSolanilla, E., Berrocal-Lobo, M., et al. (2001). Antibiotic activities of peptides, hydrogen peroxide and peroxynitrite in plant defence. FEBS Lett. 498, 219-222. doi: 10.1016/S0014-5793(01)02456-5

Giberti, S., Bertea, C. M., Narayana, R., Maffei, M. E., and Forlani, G. (2012). Two phenylalanine ammonia lyase isoforms are involved in the elicitor-induced response of rice to the fungal pathogen Magnaporthe oryzae. J. Plant Physiol. 169, 249-254. doi: 10.1016/j.jplph.2011.10.008

Gille, S., de Souza, A., Xiong, G., Benz, M., Cheng, K., Schultink, A., et al. (2011). O-acetylation of Arabidopsis hemicellulose xyloglucan requires AXY4 or AXY4L, proteins with a TBL and DUF231 domain. Plant Cell 23, 4041-4053. doi: 10.1105/tpc.111.091728

Gille, S., and Pauly, M. (2012). O-acetylation of plant cell wall polysaccharides. Front. Plant Sci. 3:12. doi: 10.3389/fpls.2012.00012

Glazebrook, J. (2005). Contrasting mechanisms of defense against biotrophic and necrotrophic pathogens. Annu. Rev. Phytopathol. 43, 205-227. doi: 10.1146/annurev.phyto.43.040204.135923

Godiard, L., Sauviac, L., Torii, K. U., Grenon, O., Mangin, B., and Grimsley, N. H., et al. (2003). ERECTA, an LRR receptor-like kinase protein controlling development pleiotropically affects resistance to bacterial wilt. Plant J. 36, 353-365. doi: 10.1046/j.1365-313X.2003.01877.x

Halpin, C., Thain, S. C., Tilston, E. L., Guiney, E., Lapierre, C., and Hopkins, D. W. (2007). Ecological impacts of trees with modified lignin. Tree Genet. Genomes 3, 101-110. doi: 10.1007/s11295-006-0060-2

Hano, C., Martin, I., Fliniaux, O., Legrand, B., Gutierrez, L., Arroo, R. R., etal. (2006). Pinoresinol-lariciresinol reductase gene expression and secoisolariciresinol diglucoside accumulation in developing flax (Linum usitatissimum) seeds. Planta 224, 1291-1301. doi: 10.1007/s00425-0060308-y

Hatfield, R. D., Marita, J. M., Frost, K., Grabber, J., Ralph, J., Lu, F., et al. (2009). Grass lignin acylation: p-coumaroyl transferase activity and cell wall characteristics of C3 and C4 grasses. Planta 229, 1253-1267. doi: 10.1007/s00425-0090900-z
Hematy, K., Cherk, C., and Somerville, S. (2009). Host-pathogen warfare at the plant cell wall. Curr. Opin. Plant Biol. 12, 406-413. doi: 10.1016/j.pbi.2009. 06.007

Hernández-Blanco, C., Feng, D. X., Hu, J., Sánchez-Vallet, A., Deslandes, L., Llorente, F., et al. (2007). Impairment of cellulose synthases required for Arabidopsis secondary cell wall formation enhances disease resistance. Plant Cell 19, 890-903. doi: 10.1105/tpc.106.048058

Huang, J., Bhinu, V. S., Li, X., Bashi, Z. D., Zhou, R., and Hannoufa, A. (2009). Pleiotropic changes in Arabidopsis $\mathrm{f} 5 \mathrm{~h}$ and sct mutants revealed by large-scale gene expression and metabolite analysis. Planta 230, 1057-1069. doi: 10.1007/s00425009-1007-2

Huang, J., Gu, M., Lai, Z., Fan, B., Shi, K., Zhou Y. H., et al. (2010). Functional analysis of the Arabidopsis PAL gene family in plant growth, development, and response to environmental stress. Plant Physiol. 153, 1526-1538. doi: 10.1104/pp.110. 157370

Ikegawa, T., Mayama, S., Nakayashiki, H., and Kato, H. (1996). Accumulation of diferulic acid during the hypersensitive response of oat leaves to Puccinia coronate f. sp. avenae and its role in the resistance of oat tissues to cell wall degrading enzymes. Physiol. Mol. Plant Pathol. 48, 245-256. doi: 10.1006/pmpp.1996. 0021

Jiang, K., Frick-Cheng, A., Trusov, Y., Delgado-Cerezo, M., Rosenthal, D. M., Lorek, J., et al. (2012). Dissecting Arabidopsis G- $\beta$ signal transduction on the protein surface. Plant Physiol. 159, 975-983. doi: 10.1104/pp.112.196337

Kim, H., Ralph, J., Yahiaoui, N., Pean, M., and Boudet, A.-M. (2000). Crosscoupling of hydroxycinnamyl aldehydes into lignins. Org. Lett. 2, 2197-2200. doi: 10.1021/ol005906o

Kliebenstein, D. J., Lim, J. E., Landry, L. G., and Last, R. L. (2002). Arabidopsis UVR8 regulates ultraviolet-B signal transduction and tolerance and contains sequence similarity to human regulator of chromatin condensation 1. Plant Physiol. 130, 234-243. doi: 10.1104/pp.005041

Klopffleisch, K., Phan, N., Augustin, K., Bayne, R. S., Booker, K. S., Botella, J. R. et al. (2011). Arabidopsis G-protein interactome reveals connections to cell wall carbohydrates and morphogenesis. Mol. Syst. Biol. 7, 532. doi: 10.1038/msb.2011.66

Kofalvi, S. A., and Nassuth, A. (1995). Influence of wheat streak mosaic virus infection on phenylpropanoid metabolism and the accumulation of phenolics and lignin in wheat. Physiol. Mol. Plant Pathol. 47, 365-377. doi: 10.1006/pmpp.1995.1065

König, S., Feussner, K., Kaever, A., Landesfeind, M., Thurow, C., Karlovsky, P., et al. (2014). Soluble phenylpropanoids are involved in the defense response of Arabidopsis against Verticillium longisporum. New Phytol. 202, 823-837. doi: 10.1111/nph.12709

Lauvergeat, V., Lacomme, C., Lacombe, E., Lasserre, E., Roby, D., and GrimaPettenati, J. (2001). Two cinnamoyl-CoA reductase (CCR) genes from Arabidopsis thaliana are differentially expressed during development and in response to infection with pathogenic bacteria. Phytochemistry 57, 1187-1195. doi: 10.1016/S0031-9422(01)00053-X

Lee, C., Teng, Q., Zhong, R., and Ye, Z. H. (2011). The four Arabidopsis REDUCED WALL ACETYLATION genes are expressed in secondary wall-containing cells and required for the acetylation of xylan. Plant Cell Physiol. 52, 1289-1301. doi: 10.1093/pcp/pcr075

Lee, K., Dudley, M. W., Hess, K. M., Lynn, D. G., Joerger, R. D., and Binns, A. N. (1992). Mechanism of activation of Agrobacterium virulence genes: identification of phenol-binding proteins. Proc. Natl. Acad. Sci. U.S.A. 89, 8666-8670. doi: 10.1073/pnas.89.18.8666

Lee, Y. W., Jin, S., Sims, W. S., and Nester, E. W. (1995). Genetic evidence for direct sensing of phenolic compounds by the VirA protein of Agrobacterium tumefaciens. Proc. Natl. Acad. Sci. U.S.A. 92, 12245-12249. doi: 10.1073/pnas.92.26. 12245

Lionetti, V., Cervone, F., and Bellincampi, D. (2012). Methyl esterification of pectin plays a role during plant-pathogen interactions and affects plant resistance to diseases. J. Plant Physiol. 169, 1623-1630. doi: 10.1016/j.jplph.2012.05.006

Lionetti, V., Raiola, A., Camardella, L., Giovane, A., Obel, N., Pauly, M., et al. (2007). Overexpression of pectin methylesterase inhibitors in Arabidopsis restricts fungal infection by Botrytis cinerea. Plant Physiol. 143, 1871-1880. doi: 10.1104/pp.106.090803

Liu, J., Ding, P., Sun, T., Nitta, Y., Dong, O., Huang, X., et al. (2013). Heterotrimeric $\mathrm{G}$ proteins serve as a converging point in plant defense signaling 
activated by multiple receptor-like kinases. Plant Physiol. 161, 2146-2158. doi: 10.1104/pp.112.212431

Llorente, F., Alonso-Blanco, C., Sanchez-Rodriguez, C., Jorda, L., and Molina, A. (2005). ERECTA receptor-like kinase and heterotrimeric G protein from Arabidopsis are required for resistance to the necrotrophic fungus Plectosphaerella cucumerina. Plant J. 43, 165-180. doi: 10.1111/j.1365-313X.2005. 02440.x

Lo, S. C. C., and Nicholson, R. L. (1998). Reduction of light-induced anthocyanin accumulation in inoculated sorghum mesocotyls: implications for a compensatory role in the defense response. Plant Physiol. 116, 979-989. doi: 10.1104/pp.116.3.979

Lorek, J., Griebel, T., Jones, A. M., Kuhn, H., and Panstruga, R. (2013). The role of Arabidopsis heterotrimeric G-protein subunits in MLO2 function and MAMP-triggered immunity. Mol. Plant Microbe. Interact. 26, 991-1003. doi: 10.1094/MPMI-03-13-0077-R

Lozovaya, V. V., Lygin, A. V., Zernova, O. V., Ulanov, A. V., Li, S. X., Hartman, G. L., et al. (2007). Modification of phenolic metabolism in soybean hairy roots through down regulation of chalcone synthase or isoflavone synthase. Planta 225, 665-679. doi: 10.1007/s00425-006-0368-z

$\mathrm{Lu}, \mathrm{F}$, and Ralph, J. (2008). Novel tetrahydrofuran structures derived from $\beta-\beta$ coupling reactions involving sinapyl acetate in kenaf lignins. Org. Biomol. Chem. 6, 3681-3694. doi: 10.1039/b809464k

Macho, A. P., and Zipfel, C. (2014). Plant PRRs and the activation of innate immune signaling. Mol. Cell. 54, 263-272. doi: 10.1016/j.molcel.2014. 03.028

Maher, E. A., Bate, N. J., Ni, W., Elkind, Y., Dixon, R. A., and Lamb, C. J. (1994). Increased disease susceptibility of transgenic tobacco plants with suppressed levels of preformed phenylpropanoid products. Proc. Natl. Acad. Sci. U.S.A. 91, 7802-7806. doi: 10.1073/pnas.91.16.7802

Malinovsky, F. G., Fangel, J. U., and Willats, W. G. T. (2014). The role of the cell wall in plant immunity. Front. Plant Sci. 5:178. doi: 10.3389/fpls.2014. 00178

Manabe, Y., Nafisi, M., Verhertbruggen, Y., Orfila, C., Gille, S., Rautengarten, C., et al. (2011). Loss-of-function mutation of REDUCED WALL ACETYLATION in Arabidopsis leads to reduced cell wall acetylation and increased resistance to Botrytis cinerea. Plant Physiol. 155, 1068-1078. doi: 10.1104/pp.110.168989

Mandal, S., Das, R. K., and Mishra, S. (2011). Differential occurrence of oxidative burst and antioxidative mechanism in compatible and incompatible interactions of tomato and Ralstonia solanacearum. Plant Physiol. Biochem. 49, 117-123. doi: 10.1016/j.plaphy.2010.10.006

Mandal, S., Kar, I., Mukherjee, A. K., and Acharya, P. (2013). Elicitor-induced defense responses in Solanum lycopersicum against Ralstonia solanacearum. Sci. World J. 25:561056. doi: 10.1155/2013/561056

Martin, J. A., Solla, A., Woodward, S., and Gil, L. (2007). Detection of differential changes in lignin composition of elm xylem tissues inoculated with Ophiostoma novoulmi using Fourier transform-infrared spectroscopy. For. Pathol. 37, 187191. doi: 10.1111/j.1439-0329.2007.00495.x

Maury, S., Delaunay, A., Mesnard, F., Cronier, D., Chabbert, B., Geoffroy, P., et al. (2010). O-methyltransferase(s)-suppressed plants produce lower amounts of phenolic vir inducers and are less susceptible to Agrobacterium tumefaciens infection. Planta 232, 975-986. doi: 10.1007/s00425-0101230-x

Menden, B., Kohlhoff, M., and Moerschbacher, B. M. (2007). Wheat cells accumulate a syringyl-rich lignin during the hypersensitive resistance response. Phytochemistry 68, 513-520. doi: 10.1016/j.phytochem.2006. 11.011

Meyer, K., Shirley, A. M., Cusumano, J. C., Bell-Lelong, D. A., and Chapple, C. (1998). Lignin monomer composition is determined by the expression of a cytochrome P450-dependent monooxygenase in Arabidopsis. Proc. Natl. Acad. Sci. U.S.A. 95, 6619-6623. doi: 10.1073/pnas.95.12.6619

Mohr, P. G., and Cahill, D. M. (2007). Suppression by ABA of salicylic acid and lignin accumulation and the expression of multiple genes, in Arabidopsis infected with Pseudomonas syringae pv. tomato. Funct. Integr. Genomics 7, 181-191. doi: 10.1007/s10142-006-0041-4

Morreel, K., Ralph, J., Kim, H., Lu, F., Goeminne, G., Ralph, S., et al. (2004). Profiling of oligolignols reveals monolignol coupling conditions in lignifying poplar xylem. Plant Physiol. 136, 3537-3549. doi: 10.1104/pp.104. 049304
Naoumkina, M. A., Zhao, Q., Gallego-Giraldo, L., Dai, X., Zhao, P. X., and Dixon, R. A. (2010). Genome-wide analysis of phenylpropanoid defense pathways. Mol. Plant Pathol. 11, 829-846. doi: 10.1111/j.1364-3703.2010.00648.x

Oliver, A. L., Pedersen, J. F., Grant, R. J., Klopfenstein, T. J., and Jose, H. (2005). Comparative effects of the sorghum bmr-6 and bmr-12 genes: II. Grain yield, stover yield, and stover quality in grain sorghum. Crop Sci. 45, 2240-2245. doi: $10.2135 /$ cropsci2004.0660

Ong, R. G., Chundawat, S. P. S., Hodge, D. B., Keskar, S., and Dale, B. E. (2014). "Linking plant biology and pretreatment: understanding the structure and organization of the plant cell wall and interactions with cellulosic biofuel production," in Plants and BioEnergy, Advances in Plant Biology, eds M. C. McCann, M. S. Buckeridge, and N. C. Carpita (New York, NY: Springer), 231-253.

Pan, Q., Zhan, J., Liu, H., Zhang, J., Chen, J., Wen, P., etal. (2006). Salicylic acid synthesized by benzoic acid 2-hydroxylase participates in the development of thermotolerance in pea plants. Plant Sci. 171, 226-233. doi: 10.1016/j.plantsci.2006.03.012

Panstruga, R., Parker, J. E., and Schulze-Lefert, P. (2009). SnapShot: plant immune response pathways. Cell 136, 978-U976. doi: 10.1016/j.cell.2009.02.020

Parrott, D. L., Anderson, A. J., and Carman, J. G. (2002). Agrobacterium induces plant cell death in wheat (Triticum aestivum L.). Physiol. Mol. Plant Pathol. 60, 59-69. doi: 10.1006/pmpp.2002.0378

Pesquet, E., Ranocha, P., Legay, S., Digonnet, C., Barbier, O., Pichon, M., et al. (2005). Novel markers of xylogenesis in zinnia are differentially regulated by auxin and cytokinin. Plant Physiol. 139, 1821-1839. doi: 10.1104/pp.105. 064337

Petersen, P. D., Lau, J., Ebert, B., Yang, F., Verhertbruggen, Y., Kim, J. S., et al. (2012). Engineering of plants with improved properties as biofuels feedstocks by vesselspecific complementation of xylan biosynthesis mutants. Biotechnol. Biofuels 26, 84. doi: 10.1186/1754-6834-5-84

Pilate, G., Guiney, E., Holt, K., Petit-Conil, M., Lapierre, C., Leplé, J.-C., et al. (2002). Field and pulping performances of transgenic trees with altered lignification. Nat. Biotechnol. 20, 607-612. doi: 10.1038/nbt0602-607

Pogorelko, G., Lionetti, V., Fursova, O., Sundaram, R. M., Qi, M., and Whitham, S. A., et al. (2013). Arabidopsis and Brachypodium distachyon transgenic plants expressing Aspergillus nidulans acetylesterases have decreased degree of polysaccharide acetylation and increased resistance to pathogens. Plant Physiol. 162, 9-23. doi: 10.1104/pp.113.214460

Quentin, M., Allasia, V., Pegard, A., Allais, F., Ducrot, P. H., Favery, B., et al. (2009). Imbalanced lignin biosynthesis promotes the sexual reproduction of homothallic oomycete pathogens. PLoS Pathog. 5:e1000264. doi: 10.1371/journal.ppat.1000264

Raiola, A., Lionetti, V., Elmaghraby, I., Immerzeel, P., Mellerowicz, E. J., Salvi, G., et al. (2011). Pectin methylesterase is induced in Arabidopsis upon infection and is necessary for a successful colonization by necrotrophic pathogens. Mol. Plant Microbe Interact. 24, 432-440. doi: 10.1094/MPMI-07-10-0157

Ralph, J., Lundquist, K., Brunow, G., Lu, F., Kim, H., Schatz, P. F., etal. (2004). Lignins: natural polymers from oxidative coupling of 4-hydroxyphenylpropanoids. Phytochem. Rev. 3, 29-60. doi: 10.1023/B:PHYT.0000047809.65444.a4

Ramírez, V., Agorio, A., Coego, A., García-Andrade, J., Hernández, M. J., Balaguer, B., et al. (2011). MYB46 modulates disease susceptibility to Botrytis cinerea in Arabidopsis. Plant Physiol. 155, 1920-1935. doi: 10.1104/pp.110. 171843

Ranocha, P., Denancé, N., Vanholme, R., Freydier, A., Martinez, Y., Hoffmann, L., et al. (2010). Walls are thin 1 (WAT1), an Arabidopsis homolog of Medicago truncatula NODULIN21, is a tonoplast-localized protein required for secondary wall formation in fibers. Plant J. 63, 469-483. doi: 10.1111/j.1365-313X.2010. 04256.x

Ranocha, P., Dima, O., Nagy, R., Felten, J., Corratgé-Faillie, C., Novak, O., et al. (2013). Arabidopsis WAT1 is a vacuolar auxin transport facilitator required for auxin homeostasis. Nat. Commun. 4, 2625. doi: 10.1038/ ncomms 3625

Ringli, C. (2010). Monitoring the outside: cell wall-sensing mechanisms. Plant Physiol. 153, 1445-1452. doi: 10.1104/pp.110.154518

Rogers, L. A., Dubos, C., Surman, C., Willment, J., Cullis, I. F., Mansfield, S. D., et al. (2005). Comparison of lignin deposition in three ectopic lignification mutants. New Phytol. 168, 123-140. doi: 10.1111/j.1469-8137.2005. 01496.x 
Romero, D., Rivera, M. E., Cazorla, F. M., Codina, J. C., Fernández-Ortuño, D., Torés, J. A., et al. (2008). Comparative histochemical analyses of oxidative burst and cell wall reinforcement in compatible and incompatible melon-powdery mildew (Podosphaera fusca) interactions. J. Plant Physiol. 165, 1895-1905. doi: 10.1016/j.jplph.2008.04.020

Ruuhola, T., and Julkunen-Tiitto, R. (2003). Trade-off between synthesis of salicylates and growth of micropropagated Salix pentandra. J. Chem. Ecol. 29, 1565-1588. doi: 10.1023/A:1024266612585

Sampedro, J., Pardo, B., Gianzo, C., Guitián, E., Revilla, G., and Zarra, I. (2010). Lack of $\alpha$-xylosidase activity in Arabidopsis alters xyloglucan composition and results in growth defects. Plant Physiol. 154, 1105-1115. doi: 10.1104/pp.110. 163212

Sánchez-Rodríguez, C., Estevez, J. M., Llorente, F., Hernandez-Blanco, C., Jorda, L., Pagan, I., et al. (2009). The ERECTA Receptor-Like Kinase regulates cell wall mediated resistance to pathogens in Arabidopsis thaliana. Mol. Plant Microbe. Interact. 22, 953-963. doi: 10.1094/MPMI-22-8-0953

Sánchez-Vallet, A., Ramos, B., Bednarek, P., López, G., Piślewska-Bednarek, M., Schulze-Lefert, P., et al. (2010). Tryptophan-derived secondary metabolites in Arabidopsis thaliana confer non-host resistance to necrotrophic Plectosphaerella cucumerina fungi. Plant J. 63, 115-127. doi: 10.1111/j.1365-313X.2010. 04224.x

Sarkar, P., Bosneaga, E., and Auer, M. (2009). Plant cell walls throughout evolution: towards a molecular understanding of their design principles. J. Exp. Bot. 60 3615-3635. doi: 10.1093/jxb/erp245

Sattler, S. E., and Funnell-Harris, D. L. (2013). Modifying lignin to improve bioenergy feedstocks: strengthening the barrier against pathogens? Front Plant Sci. 4:70 doi: 10.3389/fpls.2013.00070

Sattler, S. E., Saathoff, A. J., Haas, E. J., Palmer, N. A., Funnell-Harris, D. L., Sarath, G., et al. (2009). A nonsense mutation in a cinnamyl alcohol dehydrogenase gene is responsible for the sorghum brown midrib 6 phenotype. Plant Physiol. 150, 584-595. doi: 10.1104/pp.109.136408

Schulze-Lefert, P. (2004). Knocking on the heaven's wall: pathogenesis of and resistance to biotrophic fungi at the cell wall. Curr. Opin. Plant Biol. 7, 377-383. doi: 10.1016/j.pbi.2004.05.004

Shadle, G. L., Wesley, S. W., Korth, K. L., Chen, F., Lamb, C., and Dixon, R. A. (2003). Phenylpropanoid compounds and disease resistance in transgenic tobacco with altered expression of l-phenylalanine ammonia-lyase. Phytochemistry 64, 153-161. doi: 10.1016/S0031-9422(03)00151-1

Shi, H., Liu, Z., Zhu, L., Zhang, C., Chen, Y., Zhou, Y., et al. (2012). Overexpression of cotton (Gossypium hirsutum) dirigentl gene enhances lignification that blocks the spread of Verticillium dahliae. Acta Biochim. Biophys. Sin. 44, 555-564. doi: 10.1093/abbs/gms035

Simmons, B. A., Loqué, D., and Ralph, J. (2010). Advances in modifying lignin for enhanced biofuel production. Curr. Opin. Plant Biol. 13, 313-320. doi 10.1016/j.pbi.2010.03.001

Smith, A. H., Gill, W. M., Pinkard, E. A., and Mohammed, C. L. (2007). Anatomical and histochemical defence responses induced in juvenile leaves of Eucalyptus globulus and Eucalyptus nitens by Mycosphaerella infection. For. Pathol. 37, 361373. doi: 10.1111/j.1439-0329.2007.00502.x

Torres, M. A., Morales, J., Sánchez-Rodríguez, C., Molina, A., and Dangl, J. L. (2013). Functional interplay between Arabidopsis NADPH oxidases and heterotrimeric G protein. Mol. Plant Microbe Interact. 26, 686-694. doi: 10.1094/MPMI-10-120236-R

Tronchet, M., Balagué, C., Kroj, T., Jouanin, L., and Roby, D. (2010). Cinnamyl alcohol dehydrogenases $\mathrm{C}$ and $\mathrm{D}$, key enzymes in lignin biosynthesis, play an essential role in disease resistance in Arabidopsis. Mol. Plant Pathol. 11, 83-92. doi: 10.1111/j.1364-3703.2009.00578.x

Trusov, Y., Jordá, L., Molina, A., and Botella, J. R. (2010). "G proteins and plant innate immunity," in Integrated G Proteins Signaling in Plants, eds S. Yalovsky, F. Baluška, and A. Jones (Berlin, Heidelberg: Springer), 221-250.

Underwood, W. (2012). The plant cell wall: a dynamic barrier against pathogen invasion. Front. Plant Sci. 3:85. doi: 10.3389/fpls.2012. 00085

Van Acker, R., Leplé, J.-C., Aerts, D., Storme, V., Goeminne, G., Ivens, B., et al. (2014). Improved saccharification and ethanol yield from field-grown transgenic poplar deficient in cinnamoyl-CoA reductase. Proc. Natl. Acad. Sci. U.S.A. 111, 845-850. doi: 10.1073/pnas.1321673111
Van Acker, R., Vanholme, R., Storme, V., Mortimer, J. C., Dupree, P., and Boerjan, W. (2013). Lignin biosynthesis perturbations affect secondary cell wall composition and saccharification yield in Arabidopsis thaliana. Biotechnol. Biofuels 6:46. doi: 10.1186/1754-6834-6-46

Vanholme, R., Cesarino, I., Rataj, K., Xiao, Y., Sundin, L., Goeminne, G., et al. (2013). Caffeoyl shikimate esterase (CSE) is an enzyme in the lignin biosynthetic pathway in Arabidopsis. Science 341, 1103-1106. doi: 10.1126/science. 1241602

Vanholme, R., Demedts, B., Morreel, K., Ralph, J., and Boerjan, W. (2010). Lignin biosynthesis and structure. Plant Physiol. 153, 895-905. doi: 10.1104/pp.110.155119

Vanholme, R., Morreel, K., Darrah, C., Oyarce, P., Grabber, J. H., Ralph, J., et al. (2012a). Metabolic engineering of novel lignin in biomass crops. New Phytol. 196, 978-1000. doi: 10.1111/j.1469-8137.2012.04337.x

Vanholme, R., Storme, V., Vanholme, B., Sundin, L., Christensen, J. H., Goeminne, G., et al. (2012b). A systems biology view of responses to lignin biosynthesis perturbations in Arabidopsis. Plant Cell 24, 3506-3529. doi: 10.1105/tpc.112. 102574

Vogel, J. P., Raab, T. K., Schiff, C., and Somerville, S. C. (2002). PMR6, a pectate lyase-like gene required for powdery mildew susceptibility in Arabidopsis. Plant Cell 14, 2095-2106. doi: 10.1105/tpc.003509

Vogel, J. P., Raab, T. K., Somerville, C. R., and Somerville, S. C. (2004). Mutations in PMR5 result in powdery mildew resistance and altered cell wall composition. Plant J. 40, 968-978. doi: 10.1111/j.1365-313X.2004.02264.x

Volpi, C., Janni, M., Lionetti, V., Bellincampi, D., Favaron, F., and D'Ovidio, R. (2011). The ectopic expression of a pectin methyl esterase inhibitor increases pectin methyl esterification and limits fungal diseases in wheat. Mol. Plant Microbe. Interact. 24, 1012-1019. doi: 10.1094/MPMI-01-11-0021

Vorwerk, S., Somerville, S., and Somerville, C. (2004). The role of plant cell wall polysaccharide composition in plant disease resistance. Trends Plant Sci. 9, 203209. doi: 10.1016/j.tplants.2004.02.005

Way, H. M., Birch, R. G., and Manners, J. M. (2011). A comparison of individual and combined l-phenylalanine ammonia lyase and cationic peroxidase transgenes for engineering resistance in tobacco to necrotrophic pathogens. Plant Biotechnol. Rep. 5, 301-308. doi: 10.1007/s11816-011-0183-2

Way, H. M., Kazan, K., Mitter, N., Goulter, K. C., Birch, R. G., and Manners, J. M. (2002). Constitutive expression of a phenylalanine ammonia-lyase gene from Stylosanthes humilis in transgenic tobacco leads to enhanced disease resistance but impaired plant growth. Physiol. Mol. Plant Pathol. 60, 275-282. doi: 10.1016/S0885-5765(02)90407-8

Weiergang, I., Hipskind, J. D., and Nicholson, R. L. (1996). Synthesis of 3deoxyanthocyanidin phytoalexins in sorghum occurs independent of light. Physiol. Mol. Plant Pathol. 49, 377-388. doi: 10.1006/pmpp.1996.0060

Wolf, S., Hématy, K., and Höfte, H. (2012). Growth control and cell wall signaling in plants. Annu. Rev. Plant Biol. 63, 381-407. doi: 10.1146/annurev-arplant-042811105449

Wróbel-Kwiatkowska, M., Starzycki, M., Zebrowski, J., Oszmiañski, J., and Szopa, J. (2007). Lignin deficiency in transgenic flax resulted in plants with improved mechanical properties. J. Biotechnol. 128, 919-934. doi: 10.1016/j.jbiotec.2006.12.030

Xu, L., Zhu, L., Tu, L., Liu, L., Yuan, D., Jin, L., et al. (2011). Lignin metabolism has a central role in the resistance of cotton to the wilt fungus Verticillium dahliae as revealed by RNA-Seq-dependent transcriptional analysis and histochemistry. J. Exp. Bot. 62, 5607-5621. doi: 10.1093/jxb/err245

Yang, F., Mitra, P., Zhang, L., Prak, L., Verhertbruggen, Y., Kim, J. S., et al. (2013). Engineering secondary cell wall deposition in plants. Plant Biotechnol. J. 11, 325-335. doi: 10.1111/pbi.12016

Yu, C. K., Springob, K., Schmidt, J., Nicholson, R. L., Chu, I. K., Yip, W. K., et al. (2005). A stilbene synthase gene (SbSTS1) is involved in host and nonhost defense responses in sorghum. Plant Physiol. 138, 393-401. doi: 10.1104/pp.105.059337

Yu, O., Jung, W., Shi, J., Croes, R. A., Fader, G. M., McGonigle, B., et al. (2000). Production of the isoflavones genistein and daidzein in non-legume dicot and monocot tissues. Plant Physiol. 124, 781-794. doi: 10.1104/pp.124. 2.781

Zhang, S. H., Yang, Q., and Ma, R. C (2007). Erwinia carotovora ssp. carotovora infection induced "defense lignin" accumulation and lignin biosynthetic gene expression in Chinese cabbage (Brassica rapa L. ssp. pekinensis). J. Integr. Plant Biol. 49, 993-1002. doi: 10.1111/j.1672-9072.2007.00478.x 
Zhao, J., Buchwaldt, L., Rimmer, S. R., Sharpe, A., Mcgregor, L., Bekkoui, D., et al. (2009). Patterns of differential gene expression in Brassica napus cultivars infected with Sclerotinia sclerotiorum. Mol. Plant Pathol. 10, 635-649. doi: 10.1111/j.13643703.2009.00558.x

Conflict of Interest Statement: The authors declare that the research was conducted in the absence of any commercial or financial relationships that could be construed as a potential conflict of interest.

Received: 30 May 2014; paper pending published: 13 June 2014; accepted: 04 July 2014; published online: 05 August 2014.
Citation: Miedes E, Vanholme R, Boerjan W and Molina A (2014) The role of the secondary cell wall in plant resistance to pathogens. Front. Plant Sci. 5:358. doi: $10.3389 / \mathrm{fpls} .2014 .00358$

This article was submitted to Plant-Microbe Interaction, a section of the journal Frontiers in Plant Science.

Copyright (c) 2014 Miedes, Vanholme, Boerjan and Molina. This is an open-access article distributed under the terms of the Creative Commons Attribution License (CC BY). The use, distribution or reproduction in other forums is permitted, provided the original author(s) or licensor are credited and that the original publication in this journal is cited, in accordance with accepted academic practice. No use, distribution or reproduction is permitted which does not comply with these terms. 